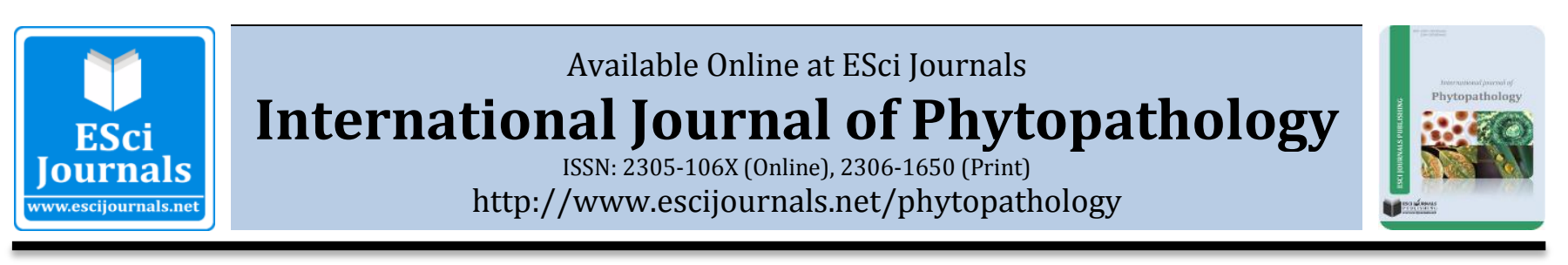

\title{
FULVIC ACID: A TOOL FOR CONTROLLING POWDERY AND DOWNY MILDEWS IN CUCUMBER PLANTS
}

\author{
aSaid M. Kamel*, bMohamed M.I. Afifi, aFathia S. El-shoraky, aMohamad M. El-Sawy \\ a Plant Pathology Research Institute, Agriculture Research Center, Giza, Egypt. \\ b Soils, Water and Environment Research Institute Agriculture Research Center, Giza, Egypt.
}

\section{A B S T R A C T}

A greenhouse experiment was carried out on cucumber cultivar DP-164 during the seasons 2012-2013 to evaluate the efficacy of three concentrations of fulvic acid (FA) to control downy and powdery mildew diseases compared with the recommended fungicides and their effects on plant growth, chlorophyll content and yield of cucumber plants. Results revealed that all FA concentrations significantly reduced disease severity of both diseases. The highest reduction in disease severity of downy mildew was recorded using $75 \mathrm{ppm}$ of FA, which was more effective than the recommended fungicide. The significant effect of inhibition of powdery mildew diseases increased gradually with increased FA concentration. At the same time, the reduction of diseases severity was greater than or equal to the recommended fungicides. Foliar application of FA concentrations and Ridomil fungicide increased significantly all morphological characters. Sumi-8 fungicide increased the morphological characters except plant height, dry weight/ plant and leaves number/ plant. The yield components (weight of fruits and mean of fruit weight /plant) recorded the same values with all FA concentrations. Fulvic acid had direct effect on soil microbiology by increasing plant exudates, which enhanced the activity of microorganism. Fulvic acid at 150ppm showed the highest increase in dehydrogenase and nitrogenase activity. This study revealed that the foliar application of FA improved plant growth and yield quantity and quality as well as controlling powdery and downy mildews of cucumber plants. Additionally, FA has the advantage as effective and environmental friendly agent.

Keywords: Control, humic substance, Podosphaera fusca, Pseudoperonospora cubensis.

\section{INTRODUCTION}

Powdery and downy mildew diseases on cucumber (Cucumis sativus L.) caused by Podosphaera fusca (syn. Sphaerotheca fuliginea) and Pseudoperonospora cubensis, respectively, are considered the most economically important and widespread diseases occurring throughout the world in both greenhouse and open fields (Sitterly, 1978; Brunelli and Davi, 1987). Although, chemical synthetic fungicides succeed to control several plant diseases, they increase production costs, incidence of health problems and pollution of environment. Therefore, a need has arisen for alternative strategies for controlling plant diseases.

Natural compounds obtained from microorganisms and organic fertilizers have the advantage of being less

\footnotetext{
* Corresponding Author:

Email: said_kamel88@yahoo.com

(C) 2014 ESci Journals Publishing. All rights reserved.
}

harmful to the ecosystem, and of being biodegraded in situ by the microflora (Sanchez Rodriguez et al., 2002). Fulvic acid extracted from the rachis of waste plants contains high concentrations of potassium and tends to induce resistance to some diseases (Alvarez et al., 2002). Studies conducted by Weltzein (1992), Yohalem et al. (1994) and cited by Alvarez et al. (2002), indicated that these lixiviates have been used for many years as foliar sprays to control fungal plant diseases. Also, studies reported by Alvarez et al. (2002) stated that the application of $5 \%$ fulvic acid extracted from banana lixiviate succeeded to reduce the severity of powdery mildew in roses.

The aim of the current research was to evaluate the use of fulvic acid extracted from waste rachis as an effective and low cost alternative controlling powdery and downy mildew diseases in cucumber, beside improving quantity and quality of yield and enhancing soil microbial activity. 


\section{MATERIALS AND METHODS}

Source of Fulvic Acid: Biogas manure sample was provided from Recycling of Agric. Residue Training Center Moshtohor, El- Kaliobiya Governorate, Egypt. Biogas manure was manufactured by drying the anaerobic cow dung effluent. Fresh cow dung was fermented in a biogas digester at retention time of 45-50 days. Table (1) shows the physical, chemical and biological properties of biogas manure. Physical parameters including moisture content and dry matter were determined according to the methods described by Black et al. (1965). Chemical parameters of electrical conductivity (EC), $\mathrm{pH}$, organic matter (OM), organic carbon (OC), $\mathrm{C} / \mathrm{N}$ ratio, total phosphorus and total potassium were determined according to standard methods of APHA, (1989), while total nitrogen (TN), ammoniacal nitrogen $\left(\mathrm{NH}_{4}{ }^{+}-\mathrm{N}\right)$, nitrate (NO3) were determined for fresh materials using the recommended methods published in Chapman and Pratt (1961). The plate count using the suitable serial dilutions and specific media was applied for estimation of the examined microbial groups. Total and fecal coliform and Salmonella and Shigella were counted according to APHA (1989).

Table 1. Physical, chemical and biological analyses of biogas samples.

\begin{tabular}{lll}
\hline S. No. & \multicolumn{1}{c}{ Content } & \multicolumn{1}{c}{ Ratio } \\
\hline 1 & Density kg/ m ${ }^{3}$ & 400 \\
2 & Moisture content \% & 17.7 \\
3 & Dry matter \% & 82.3 \\
4 & pH $(1: 10)$ & 7.51 \\
5 & EC dS/m (1:10) & 3.75 \\
6 & Ammonia ppm & 51.7 \\
7 & Nitrate ppm & 277.3 \\
8 & Total Nitrogen \% & 1.36 \\
9 & Organic matter \% & 54.80 \\
10 & Organic carbon \% & 31.78 \\
11 & Ash \% & 45.2 \\
12 & Carbon/ nitrogen ratio & $23: 1$ \\
13 & Total Phosphorus \% & 0.69 \\
14 & Total Potassium \% & 0.58 \\
15 & Total coliform cfu /g x10 & nd \\
16 & Faecal coliformx cfu/g 10 & nd \\
17 & Salmonella and Shigella cfu/g x $10^{1}$ & nd \\
18 & Parasites & nd \\
\hline
\end{tabular}

nd: not detected

Extraction and Purification of Fulvic Acid: Extraction of fulvic acid was done from biogas manure according to the method described by Sanchez et al., (2002).
Purification of fulvic acid was done as described by Kononova (1966). The chemical properties of fulvic acid were determined as total phosphorus reluctance (Murphy and Riley, 1962) and total potassium by using a flame photometer (Chapman and Pratt, 1961). Elemental analysis $\left(\mathrm{C}, \mathrm{H}, \mathrm{N}, \mathrm{S}\right.$ and $\mathrm{O}_{2}$ ) of the purified fulvic acid was performed by gas microanalyser (Vario elementor $\mathrm{C}, \mathrm{H}$, N, S Germany 2004) as described by Goh and Stevenson (1971). Total acidity of fulvic acid was determined following the method described by Dragunova (1958). Carboxyl groups were determined as described by Schnitzer and Gupta (1965), while phenolic groups as described by Kononova (1966).

Greenhouse Experiment: An experiment was carried out under plastic greenhouse at Sakha Agricultural Research Station, Agricultural Research Center, during the seasons 2012-2013 using cucumber cultivar DP164. Cucumber seeds were planted for 25 days. Seedlings were transplanted on two sides of the ridge at spacing of $50 \mathrm{~cm}$ between plants and $30 \mathrm{~cm}$ within the row. The treatments were accomplished before appearance of downy and powdery mildews. Each greenhouse was divided to equal experimental units (replicates), each unit contained 12 plants. These plants were distributed in 3 rows; each row was $0.7 \mathrm{~m}$ wide and $2 \mathrm{~m}$ length. Plants were irrigated whenever needed and fertilized with calculated doses of the mineral elements as recommended. Fulvic acid (added as three concentrations 50,75 and $150 \mathrm{ppm}$ ) [based on the previous experience of conducting the selection of optimal concentrations] was mixed with an adhesive surfactant (bio-film 1265, registered by Ministry of Agric., Egypt) at rate $30 \mathrm{ml} / 100 \mathrm{~L}$ and hand homogenized before fine spraying onto the upper and lower leaf surface of plants (21 days old). Another set of plants were sprayed by using water which mixed with the adhesive surfactant served as control treatment. Two synthetic fungicides applications [(1,2, ethanediylbis (carbamodithioato)) (2-) manganese mixture with $(1,2$, ethanediylbis (carbamodithioato)) (2-) zinc ](Ridomil Gold MZ 68 WG Syngenta) at the concentration $250 \mathrm{~g} / 100 \mathrm{~L}$ for downy mildew and [(E)-(R)-1-(2,4-Dichlorophenyl)4,4-Dimethyl-2-(1H-1,2,4-triazol-1-yl)-1-penten-3ol)]( Sumi-8 5\%) obtained from Somotomo Chemical Ltd, Japan at the concentration $35 \mathrm{~cm} 3 / 100 \mathrm{~L}$ for powdery mildew were conducted for comparison. Spraying was repeated weekly. All treatments were 
applied as protective agents (before appearance of symptoms).

Disease Assessment: Severity of powdery and downy mildews was assessed based on the percentage of affected leaf area. Percentage of protection was expressed as (Check-treatment/Check) x 100. It was worthy to calculate the disease inhibition (DI \%) to evaluate the real comparable efficacy of treatments.

Plant Parameters Measurements: Plant growth parameters (plant height, leaves number/plant, leaf area, fresh and dry weight) and yield components (fruit number/plant, fruit weight, yield/plant) were estimated at harvesting stage, which extended for 90 days. Additionally, total chlorophyll content was determined by using SPAD-501 portable leaf chlorophyll meter (Minolta Corp) (Yadava, 1986). Shoot fresh and dry weight of plants $\left(80^{\circ} \mathrm{C}\right.$ for 36 hours) were measured. Average number and weight of fruits/plant were estimated by harvesting fruits at marketable size. Harvesting was repeated day after day and extended for 90 days, and the accumulated yield was expressed as number and weight of fruits / plant.

Statistical Analysis: The randomized complete block design was used. The data were subjected to analysis of variance (ANOVA) using XLSTAT PRO statistical analysis

software (Addinsoft). The experiments were repeated at least three times, and treatment means were separated using a Fisher's least significant difference (LSD) test. All analyses were conducted at a significance value of $P \leq$ 0.05 .

\section{RESULTS}

Characteristics of Biogas Manure: Data presented in Table (1) show the chemical and physical properties in biogas manure. The density of manure was $400 \mathrm{~kg} / \mathrm{m}^{3}$. It is suitable for extraction of fulvic acid (FA), because the density of manure should not exceed $700 \mathrm{~kg} / \mathrm{m}^{3}$. Biogas manure is more mature when ammonia contents are lower meanwhile, nitrate content is high (Zucconi and de Bertoldi, 1987). It was worthy to notice that the organic matter in biogas sample recorded up to $54 \%$.

The C: $\mathrm{N}$ ratio of the sample was 23:1 resembling the optimum less than 25: 1 for the mature manure as stated by TMECC (2002). The total phosphorus and total potassium in biogas manure were 0.69 and 0.58 , respectively. The biogas sample recorded no existence of pathogenic bacteria and parasites. Data in Table (2) show the main characteristic of FA extracted from biogas manure. Phenolic groups were higher than both total acidity and carboxylic groups. Moreover, fulvic acid contained NPK and high percentages of carbon, Table 2. Characteristic of the fulvic acid (FA) extracted from biogas manure.

\begin{tabular}{lccccccccccc}
\hline \multicolumn{2}{c}{ Treatment } & $\mathrm{C} \%$ & $\mathrm{~N} \%$ & $\mathrm{H} \%$ & $\mathrm{~S} \%$ & $\mathrm{O}_{2} \%$ & $\begin{array}{c}\mathrm{P} \\
\mathrm{ppm}\end{array}$ & $\begin{array}{c}\mathrm{K} \\
\mathrm{ppm}\end{array}$ & $\begin{array}{c}\text { Total acidity } \\
(\mathrm{mmol} / 100 \mathrm{~g})\end{array}$ & $\begin{array}{l}\text { CooH group } \\
(\mathrm{mmol} / 100 \mathrm{~g})\end{array}$ & $\begin{array}{l}\text { Phenolic group } \\
(\mathrm{mmol} / 100 \mathrm{~g})\end{array}$ \\
\hline $\begin{array}{l}\text { KOH } \\
1.0 \mathrm{~N} .\end{array}$ & FA Bio. m. & 48.6 & 2.8 & 4.3 & 2.3 & 42.0 & 0.016 & 0.240 & 600 & 300 & 650 \\
\hline
\end{tabular}

hydrogen and sulfur. Effect of FA on Downy Mildew

Disease: Data in Table (3) show that all concentrations of FA (50, 75 and $150 \mathrm{ppm})$ and the fungicide Ridomil significantly decreased disease severity compared with control treatment. Fulvic acid at concentration $75 \mathrm{ppm}$ achieved the best result for disease inhibition (78.33\%), while the recommended fungicide Ridomil recorded $60.0 \%$. Fulvic acid showed significant antifungal activity against downy mildew of cucumber. However, these results represent the first report of FA against downy mildew of cucumber.

Effect of FA on Powdery Mildew Disease: Data in Table (4) demonstrated that FA at $150 \mathrm{ppm}$ was more efficient for controlling powdery mildew on cucumber plants. The fungicide, Sumi-8, succeeded to decrease disease severity to $5.7 \%$, similar to recorded value by FA at $75 \mathrm{ppm}$.

Effect of FA on Soil Dehydrogenase and Nitrogenase
Enzymes: Different concentrations of FA showed good effect on the activity of soil microorganisms. All fulvic acid concentrations increased activity of dehydrogenase and nitrogenase enzymes. The percentage increase at a concentration of $75 \mathrm{ppm}$ in the case of dehydrogenase enzyme (50.3\%), while concentration $50 \mathrm{ppm}$ achieved $(53.7 \%)$ in the case of an nitrogenase enzymes. Sumi-8 treatment had negative effect on soil microorganisms which appeared in low enzyme activities. On the other hand, Ridomil fungicide had positive effect on soil microorganisms, which may be due to its short half age period in plant (Table 5).

Plant Growth Parameters: Botanical measures represented in Table (6) showed that all FA concentrations and Ridomil treatments significantly increased growth parameters with different extent. In this respect, application of FA came in the top of the mentioned treatments in increasing plant height and leave number/plant. 
Table 3. Impact of different concentrations of fulvic acid (FA) on cucumber downy mildew.

\begin{tabular}{lcc}
\hline Treatments & Disease Severity (\%) & Disease Inhibition (\%) \\
\hline Fulvic acid (50) ppm & $11^{\mathrm{b}} \pm 0.82$ & 63.33 \\
Fulvic acid (75) ppm & $6.5^{\mathrm{a}} \pm 0.41$ & 78.33 \\
Fulvic acid (150) ppm & $9^{\mathrm{a}} \pm 0.82$ & 70.00 \\
Ridomil & $12^{\mathrm{b}} \pm 1.63$ & 60.00 \\
Control & $30^{\mathrm{c}} \pm 1.63$ & - \\
\hline Means followed by the same letter (s) within a column & in each block are not significantly different $(P \leq 0.05)$. \\
\multicolumn{2}{l}{ Table 4. Impact of different concentrations of fulvic acid (FA) on cucumber powdery mildew. } \\
\hline \multicolumn{2}{l}{ Treatments } & Disease Severity (\%) \\
\hline FA (50) ppm & $8^{\mathrm{a}} \pm 1.14$ & Disease Inhibition (\%) \\
FA (75) ppm & $5.7^{\mathrm{a}} \pm 0.81$ & 73.33 \\
FA (150 ppm & $5.3^{\mathrm{a}} \pm 0.76$ & 81.00 \\
Sumi-8 & $5.7^{\mathrm{a}} \pm 0.81$ & 82.33 \\
Control & $30^{\mathrm{b}} \pm 4.28$ & 81.00 \\
\hline
\end{tabular}

Means followed by the same letter (s) within a column in each block are not significantly different $(P \leq 0.05)$.

Table 5. Effect of different treatments on soil dehydrogenase and nitrogenase enzymes.

\begin{tabular}{cccc}
\hline \multirow{2}{*}{ Treatment } & Periods & \multicolumn{2}{c}{ Enzymes } \\
\cline { 3 - 4 } FA (50) ppm & Initial & Dehydrogenase UgTPF/100g & Nitrogenase n.mol $\mathrm{C}_{2} \mathrm{H}_{4} / \mathrm{g}$ dry soil/hour \\
& Final & 15.1 & 0.4269 \\
& Increase & 16.7 & 0.6562 \\
\multirow{3}{*}{ FA (75) ppm } & $10.6 \%$ & $53.7 \%$ \\
& Initial & 19.5 & 0.4866 \\
& Final & 29.3 & 0.7121 \\
& Increase & $50.3 \%$ & $46.3 \%$ \\
FA (150) ppm & Initial & 39.6 & 0.8015 \\
& Final & 44.1 & 0.9564 \\
& Increase & $11.4 \%$ & $19.3 \%$ \\
& Initial & 13.4 & 0.342 \\
& Final & 12.3 & 0.1652 \\
& Increase & $-8.2 \%$ & $-51.7 \%$ \\
& Initial & 14.0 & 0.395 \\
& Final & 18.1 & 0.5418 \\
& Increase & $29.3 \%$ & $37.2 \%$ \\
& Initial & 12.3 & 0.239 \\
& Final & 12.8 & 0.3108 \\
& Increase & $4.1 \%$ & $30.0 \%$ \\
\hline
\end{tabular}

Table 6. Influence of different concentrations of fulvic acid (FA) on plant growth parameters of cucumber plants during the season 2012/2013.

\begin{tabular}{|c|c|c|c|c|c|c|}
\hline \multirow[b]{2}{*}{ Treatments } & \multicolumn{6}{|c|}{ Plant Growth Parameters } \\
\hline & $\begin{array}{l}\text { Plant Height } \\
\text { (cm) }\end{array}$ & $\begin{array}{c}\text { Total chlorophyll } \\
\text { (SPAD) }\end{array}$ & $\begin{array}{c}\text { Leave } \\
\text { number / plant }\end{array}$ & $\begin{array}{c}\text { Leaf area } \\
\left(\mathrm{cm}^{2}\right)\end{array}$ & $\begin{array}{c}\text { Fresh weight/ } \\
\text { plant (g) }\end{array}$ & $\begin{array}{c}\text { Dry weight/ } \\
\text { plant }(\mathrm{g})\end{array}$ \\
\hline FA (50) ppm & $273.4^{\mathrm{a}} \pm 3.27$ & $40.8^{\mathrm{ab} \pm 0.57}$ & $35.0^{\mathrm{b}} \pm 1.15$ & $317.3^{b c} \pm 21.2$ & $33.0^{\mathrm{ab}} \pm 1.15$ & $5.2 \mathrm{a} \pm 0.56$ \\
\hline FA (75) ppm & $280.0^{\mathrm{a}} \pm 5.77$ & $42.7^{a} \pm 3.88$ & $42.3^{\mathrm{a} \pm 1.85}$ & $347.6^{\mathrm{ab}} \pm 26.46$ & $32.0^{c} \pm 1.15$ & $5.2^{\mathrm{a}} \pm 0.72$ \\
\hline FA (150) ppm & $293.3^{\mathrm{a}} \pm 8.81$ & $43.0^{\mathrm{a}} \pm 1.09$ & $42.6^{\mathrm{a}} \pm 2.30$ & $401.3^{a} \pm 14.2$ & $37.1^{\mathrm{a} \pm 1.07}$ & $6.5^{\mathrm{a} \pm 0.56}$ \\
\hline Sumi-8 & $193.3^{c} \pm 12.01$ & $37.4^{\mathrm{ab}} \pm 2.82$ & $24.7^{c} \pm 0.33$ & $400.7 \mathrm{a} \pm 35.45$ & $36.1^{\mathrm{ab}} \pm 1.35$ & $4.7 \mathrm{a} \pm 0.58$ \\
\hline Ridomil & $270.0^{\mathrm{a}} \pm 5.77$ & $44.9^{\mathrm{a}} \pm 2.80$ & $36.0^{\mathrm{b}} \pm 2.51$ & $370.3^{\mathrm{ab}} \pm 0.88$ & $36.3^{b} \pm 1.12$ & $6.0^{\mathrm{a}} \pm 0.60$ \\
\hline Control & $245.0^{\mathrm{b}} \pm 2.88$ & $33.5^{\mathrm{b}} \pm 2.25$ & $26.3^{c} \pm 2.18$ & $276.3^{c} \pm 9.49$ & $27.6^{\mathrm{d}} \pm 1.18$ & $4.7^{\mathrm{a}} \pm 0.49$ \\
\hline
\end{tabular}

Means followed by the same letter (s) within a column in each block are not significantly different $(P \leq 0.05)$. 
Both FA at 150 ppm and Sumi-8 fungicide treatments showed the best effects on leaf area (401.3, 400.7 $\mathrm{cm}^{2}$ ) respectively. Fulvic acid concentration at 150 ppm achieved the best result in fresh weight compared with control treatment $(37.1 \mathrm{~g})$. No significant differences were found between treatments in dry weight. The chlorophyll content in fresh plants was determined as shown in Table (6). The fungicide Ridomil was the best treatment in chlorophyll pigment (44.9 SPAD) followed by FA at both $150 \mathrm{ppm}$ and $75 \mathrm{ppm}$ (43.0 SPAD). No significant differences were found between Ridomil fungicide and FA.

Yield Components: The yield as average number and weight of fruits/plant were significantly increased using different concentrations of FA. The application of fungicides (Sumi-8 and Ridomil) induced the same trend on yield components (Table 7).

Table 7. Influence of different concentrations of fulvic acid on yield components of cucumber.

\begin{tabular}{lccc}
\hline \multirow{2}{*}{ Treatments } & \multicolumn{3}{c}{ Yield parameters } \\
\cline { 2 - 4 } & $\begin{array}{c}\text { Average } \\
\text { Fruit number / plant }\end{array}$ & $\begin{array}{c}\text { Average weight / fruit } \\
(\mathrm{g})\end{array}$ & $\begin{array}{c}\text { Mean yield/plant } \\
(\mathrm{kg})\end{array}$ \\
\hline FA (50) ppm & $33.7^{\mathrm{bc} \pm 0.88}$ & $81.0^{\mathrm{b}} \pm 8.66$ & $2.73^{\mathrm{ab}} \pm 0.16$ \\
FA (75) ppm & $36.0^{\mathrm{b}} \pm 2.0$ & $82.3^{\mathrm{b}} \pm 12.8$ & $2.96^{\mathrm{a}} \pm 0.47$ \\
FA (150) ppm & $41.3^{\mathrm{a} \pm 1.2}$ & $81.0^{\mathrm{b} \pm 4.58}$ & $3.35^{\mathrm{a}} \pm 0.12$ \\
Sumi-8 & $24.0^{\mathrm{c}} \pm 1.5$ & $86.0^{\mathrm{a}} \pm 11.53$ & $2.06^{\mathrm{bc} \pm 0.03}$ \\
Ridomil & $33.0^{\mathrm{b}} \pm 1.73$ & $91.0^{\mathrm{a}} \pm 8.71$ & $3.00^{\mathrm{a}} \pm 0.29$ \\
Control & $19.0^{\mathrm{d} \pm 1.73}$ & $75.0^{\mathrm{c}} \pm 6.51$ & $1.43^{\mathrm{c}} \pm 0.02$ \\
\hline
\end{tabular}

Means followed by the same letter (s) within a column in each block are not significantly different $(P \leq 0.05)$.

\section{DISCUSSION}

The biogas sample suppresses both pathogenic bacteria and parasites (Iannotti et al., 1993). In general, humic substances are a suspension based on potassium humates which can be applied successfully in many areas of plant production as a plant growth stimulant or soil conditioner for enhancing natural resistance against plant diseases and pests (Scheuerell and Mahaffee, 2004, 2006). Furthermore, El-Ghamry et al. (2009) indicated that the use of humic substances as foliar application improve growth and mineral content as well as decrease the damage of chocolate spot and rust diseases of faba bean. The role of humic substances in overcoming the harmful effects of diseases in plants may be due to the increase in chitinase activity (Abd-El- Kareem, 2007), moreover, regulating hormone level, improving plant growth and enhancing stress tolerance (Piccolo et al., 1992). Humic substances contain three types of organic acid; humin, humic acid and fulvic acid. They have been defined in humic science in accordance with their solubility characteristics (IHSS, 2004). Fulvic acid is a group of subclasses of an entire large class of humic substances compounds. Fulvic Acid is especially active in dissolving minerals and metals when they are in solution with water. Metallic minerals simply dissolve into the fulvic structure and become bio-chemically reactive and mobile (BioAg Technologies International, 1999). Fulvic acid mainly consists of mixtures of polycyclic phenolic compounds. Phenolic compounds play a major role in plant defense which is much higher than both total acidity and carboxylic groups in diseases management (Hahlbrock and Scheel, 1989). Moreover, FA contains high percentage of carbon, hydrogen and sulfur which are active agent in controlling plant diseases, especially powdery and downy mildews.

The foliar application of FA at all concentrations showed visible reduction of downy mildew severity compared with control treatment. The highest reduction was recorded with FA at75 ppm, while, reduction in powdery mildew severity occurred ascending with increased FA concentrations. The percentage of reduction was equal for both of powdery mildew fungicide and FA at $75 \mathrm{ppm}$. Interestingly, Neil (2012) found that FA has the nature to be an effective antifungal agent. This result is in agreement with the findings of Sherry et al. (2011). The efficacy of fulvic acid treatment against powdery mildew fungus may be due to the ability of fulvic acid to induce resistance to some diseases (Alvarez et al., 2002). Foliar application of FA (25\% active FA) consistently enhanced antioxidants such as $\alpha$-tocopherol, $\alpha$-carotene, superoxide dismutase, and ascorbic acid concentrations in turf grass species (Zhang, 1997). This antioxidant may play a role in the regulation of plant development, flowering and inducing of disease resistance (Ziadi et al., 2001; Dmitrier et al., 2003). Additionally) these results indicated that the fulvic acid treatment is a viable, 
environmentally friendly alternative for managing fungal diseases (Escobar-Vélez and Castaño-Zapata, 2005; Velez and Zapata, 2005; Elisabetta et al., 2008; Fahril and Murat, 2008; Afifi, 2010; Derbalah et al., 2012).

Application of FA showed significant increases in growth parameters and morphological characteristics of cucumber plants. Increasing of growth parameters enhanced fruits quality and yield which led to reduce the reliance on synthetic fertilizers. Fulvic acid and humic acid are excellent foliar fertilizer carriers and activators. Application of humic acids or FA in combination with trace elements and other plant nutrients, as foliar sprays, can improve the growth of plant foliage, roots and fruits. By increasing plant growth processes within the leaves an increase in carbohydrates content of the leaves and stems occurs. These carbohydrates are then transported down the stems into the roots where they are released as root exudates to provide nutrients for various soil microorganisms on the rhizoplane and the rhizosphere. Then, soil microorganisms release acids and other organic compounds which increase the availability of plant nutrients. Other microorganisms release "hormone-like" compounds which are taken up by plant roots (Achuo et al., 2004). Afifi (2010) found that FA extracted from compost (chicken manure and vegetable wastes) increased the numbers of actinomycetes in soil, while FA extracted from biogas manure increased total count of bacteria, fungi and actinomycetes. Additionally, humic substances stimulate plant growth by the assimilation of major and minor elements, enzyme activation and/or inhibition, changes in membrane permeability, protein synthesis and finally the activation of biomass production (Mackowiak et al., 2001; Ulukon, 2008). Russo and Berlyn (1990) reported that humic substances (granular and liquid forms) can reduce plant stress that involved plant diseases as well as enhance plant nutrient uptake. Humic substances contribute significantly to water retention and metal/solute binding and release, and they are necessary for safe plant nutrition (Mac Carthy et al., 1990; Stevenson, 1994). In addition, FA can be used as a growth regulator by regulating endogenous hormone levels (Frgbenro and Agboola, 1993; Piccolo et al., 1992). This is because FA binds with minerals and other molecules and transform them. Finally, several studies demonstrated that humic and fulvic acids preparations increased the uptake of mineral elements (Maggioni et al., 1987; De Kreij and Basar, 1995), promote the root length (Vaughan and Malcolm, 1979; Canellas et al., 2002) and increase the fresh and dry weight of crop plants ( Kauser and Azam, 1985; Chen et al., 2004a, b ).

In conclusion, due to the positive effects of fulvic acid on controlling both downy and powdery mildew diseases and increasing cucumber growth and yield, we suggest that FA can be inserted in an integrated management program of these diseases, with a reduced application of synthetic fungicides.

\section{REFERENCES}

Abdel-Kareem, F. 2007. Induced resistance in bean plants against root rot and Alternaria leaf spot diseases using biotic and a biotic inducers under field conditions. Journal of Agricultural and Biological Sciences 3: 767 - 774.

Achuo, E.A., K.Audenaert, H.Meziana, M.Hofte.2004. The salicylic acid dependent defence pathway is effective against different fungi in tomato and tobacco. Plant Pathology 53: 65 - 72.

Afifi, M.M.I. 2010. Biochemical studies on humic substances extracted from organic fertilizers. Ph.D. Thesis, Diss, Fac. Agric., Cairo Univ., Egypt.

Alvarez, E., C.Grajales, J. Villegas, J.Loke. 2002. CIAT Informe Anual. Control del mildeo polvoso (Sphaerotheca panosa var. rosae) en rosa, usando un lixiviado de compost del raquis de plátano (Musa AAB). (Available online with updates at http://www.ciat.cgiar.org/ipm/pdfs/cassava $\% 20$ _ Pathology.pdf).

American Public Health Association (APHA).1989. Municipal Refuse Disposal 3rd Ed. Public AdministrationService, Chicago, USA.

BioAg Technologies International. 1999. Humid acid structure and properties. Available Online at: Last Accessed: September 11, 2006. Ag Technologies International at 916: 371-694. (Available online with updates athttp://www.phelpstekcom/ graphics/bioag/humic acid. Pdf).

Black, C.A., D.O.Evans's, L.E.Ensmunger, J.L.White, F.E.Clark, R.C.Dineure. 1965. Methods of Soil Analysis II, Chemical and Microbiological Properties. American Soc. Argon. Madison, Wisconsin, USA.

Brunelli, A., R.Davi. 1987. Peronospora disease of cucurbits. Informator Fitipatologico 37: 17-20.

Canellas, L.P., F.L.Olivares, A.L.Okorokova-Facanha, A.R.Facanha. 2002. Humic acids isolated from 
earthworm compost enhance root elongation, lateral root emergence and plasma membrane $\mathrm{H}$ ATPase activity in maize roots. Plant Physiology 130: 1951-1957.

Chapman, H.D., F.P.Pratt. 1961. Methods of Analysis for Soils, Plants and Water. Univ. California, Div. Agric., Sci. Riverside, USA. No. 309 p.

Chen, Y., C.Clapp, E.Magen.2004a. Mechanisms of plant growth stimulation by humic substances: The role of organo-iron complexes. Soil Science and Plant Nutrition 50: 1089-1095.

Chen, Y., M.D.Nobili, T.Aviad. 2004b. Stimulatory Effect of Humic Substances on Plant Growth. In: Magdoft. F. and R. Ray (Eds.): Soil Organic Matter in Sustainable Agriculture, CRC Press, Washington DC. pp 103.

De Kreij, C., H.Basar.1995. Effect of humic substances in nutrient film technique on nutrient uptake. Journal of Plant Nutrition 18: 793-802.

Derbalah, A. S., S. Z. Morsy, S. M. kamel and M. M. ElSawy, 2012. Recent Approaches towards Controlling Powdery Mildew of Pepper under Greenhouse Conditions. Egyptian Journal of Biological Pest Control, 22(2): 205-210.

Dmitrier, A., M.Tena, J.Jorrin. 2003. Systemic acquired resistance in sunflower (Helianthus annuusL.). Tsitologiya-1-Genetika 37: 9-15.

Dragunova, A.F.1958. A rapid method for determining functional groups in humic acids. Nauch Trudy, Mosk. I in Zh. Chonon Inst. Ser. Khinprioz-vod., Cited by Kononova (1966), $544 \mathrm{p}$.

El-Ghamry, A.M., K.M.Abd El-Hai, K.M.Ghoneem.2009. Amino and humic acids promote growth, yield and disease resistance of faba bean cultivated in clayey soil. Australian Journal of Basic and Applied Sciences 3: 731-739.

Elisabetta, L., B. Mariagrazia,S.Nicola. 2008. The role of humic fractions from soil and compost in controlling the growth in vitro of phytopathogenic and antagonistic soil-borne fungi. Ecotoxicology and Environmental Safety 69: 350 - 357.

Escobar Velez, J.H., J.Castaño Zapata. 2005. Fulvic acid applications for the management of diseases caused by Mycosphaerella spp. InfoMusa 14:15-17.

Fahri, Y, D.S. Murat.2008. Effect of Humic Acid Applications on the Root-Rot Diseases Caused by Fusarium spp. on Tomato Plants. Plant Pathology Journal 7: 179-182.
Frgbenro, J.A., A.A.Agboola.1993. Effect of different levels of humic acid on growth and nutrient uptake of teak seedlings. Journal of Plant Nutrition 16: 1465-1483.

Goh, K.M., F.J.Stevenson.1971. Comparison of infra-red spectra of synthetic and neutral humic and fulvic acids. Soil Science 112: 392-400.

Hahlbrock, K., D.Scheel.1989. Physiology and molecular biology of phenyl propanoid metabolism. Annu. Rev. Plant Physiol. Plant Mol. Biol. 40: 347-369.

Iannotti, D.A., T. Pang,B.L.Troth, D.L.Elwell, H.M.Keener, H.A.J.Hoitink.1993. A quantitative respirometric method for monitoring compost stability. Compost Science and Utilization 1:52-65.

IHSS. 2004. International Humic Substances Society. Isolation of Samples, IHSS Vol. 2006. (Available online with updatesat http://www.ihss.gatech.edu, on-line 8.1.2006).

Kauser, A.M., F.Azam. 1985. Effect of humic acid on wheat (Triticum aestivum L.) seedling growth. Environ. Exp. Bot. 25: 245-252.

Kononova, M.M. 1966. Soil Organic Matter. Pergmon Press, Oxford, London, Edinburgh, New York, 544 p.

MacCarthy, P., C.E.Clapp, R.L.Malcolm, R.Bloom. 1990. Humic substances in soil and crop scienes: Selected Readings, American Society of Agronomy, Madison, Wisconsin.Mackinney, G., 1941.

Mackowiak, C.L., P.R.Gross, B.G.Bugbee.2001. Beneficial effects of humic acid on micronutrient availability to wheat. Soil Science Society American Journal 56: 1744-1750.

Maggioni, A., Z. Varanini,S.Nardi, R.Finton.1987. Action of soil humic matter on plant roots: Stimulation of ion uptake and effects on $\left(\mathrm{Mg}^{\prime} .+\mathrm{K}\right)$ ATPase activity. Sci. Tot. Environ 62: 355-363.

Murphy, J., J.P.Riley. 1962. A modified single solution method for the determination of phosphatic in natural water. Anal. Chem. Acta 27:31-36.

Neil, B. 2012. Fulvic acid- the natural antifungal. Available online from http://www.ezinearticles. com/?expert=Neil_Butterfield.

Piccolo, A., S. Nardi,G.Concheri.1992. Structural characteristics of humic substances as regulated to nitrate uptake and growth regulation in plant systems. Soil Biochem 24: 373-380.

Russo, R.O., G.P.Borlyn. 1990. The use organic biostimulants to help low input sustainable agriculture. J. Sust. Agric 1: 19-42. 
Sánchez Rodríguez, R., J.A.Pino Algora, C.Vallin Plous,M.E.Pérez Rodríguez, Y.Iznaga Sosa, F. Malpartida Romero.2002. Effects of the natural fungicide F20 on black Sigatoka disease (Mycosphaerella fijiensis Morelet) on plantain (AAB) and banana (AAA). IN FOM USA 11:14-16.

Scheuerell, S.J., W.H.Mahaffee.2004. Compost Tea as a Container Medium Drench for Suppressing Seedling Damping-Off Caused by Pythium ultimum. Phytopathology 94: 1156-1163.

Scheuerell, S.J., W.H.Mahaffee.2006. Variability Associated with Suppression of Gray Mold (Botrytis cinerea) on Geranium by Foliar Applications of Nonaerated and Aerated Compost Teas. Plant Disease 90: 1201-1208.

Schnitzer, M., U.C.Gupta. 1965. Determination of acidity in soil organic matter. In: (Schnitzer, M. and Khan, S.U. (eds): Soil Organic Matter. Soil Sci. Soc. Amer. Proc 29: $274-277$.

Sherry, L., C. Murray,G.Ramage. 2011. Carbohydrate derived fulvic acid (CHD-FA) is a novel antifungal product category: Front Microbiol 3: 116.

Sitterly, W.R. 1978. Powdery mildew of cucurbits. In: Spencer, D. M. (ed): The powdery mildews. Academic press, New York, San Francisco, pp 359- 379.

Stevenson, F.J. 1994. Humus Chemistry: Genesis, Composition, Reaction (Second Ed.), Wiley, New York, USA.

TMECC. 2002. Test methods for the examination of composting and composts. ed. Wayne Thompson. The US Composting Council. US Government printing office.

Ulukon, H. 2008. Effect of soil applied humic acid at different sowing times on some yield components in wheat (Triticum spp.) hybrids Int. J. Bot. 4: 164-175.
Vaughan, D., R.E.Malcolin. 1979. Effect of humic acid on invertase synthesis in roots of higher plants. Soil Biol. Biochem.11: 247-252.

Velez, J.H.E., J.C.Zapata. 2005. Fulvic acid applications for the management of diseases caused by Mycosphaerella spp. InfoMusa 14: 15-17.

Weltzien, H.C. 1992. Biocontrol of foliar fungal diseases with compost extracts. In: J.H. Andrews and S.S. Hirano (Eds.): Microbial Ecology of Leaves. Springer-VerlagPublishers, New York, USA.

Yadava, U.L. 1986. A rapid and non destructive method to determine chlorophyll in intact leaves. Hort. Sci. 21: 1449 .

Yohalem, D.S., R.F.Harres, J.H.Andrews. 1994. Aqueous extracts of spent mushroom substrate for foliar disease control. Compost Sci. Util. 2: 67-74.

Zhang, X. 1997. Influence of plant growth regulators on turfgrasss growth, antioxidant status, and drought tolerance. Ph.D. Diss., Fac. of Virginia Polytechni. (Institute and State University).

Ziadi, S, S.Barbedette, J.F.Godard, C.Monoti, L.E.D.Corre, D.Silue, D.Lecorre. 2001 Production of pathogenesis related protein in the cauliflower (Brassica oleacea var. botrytis) downy mildew (Peronospora parasistica) pathosystem treated with acidbenzolar-5-methyl. Plant Pathology 50: 579-586.

Zucconi, F., M.de Bertoldi.1987. Compost specification for the production and characterisation of compost from municipal solid waste. In: M. de Bertoldi, M.P. Ferranti, P. L'Hermite, F. Zucconi (Eds:): Compost, production, Quality and Use. Elsevier Applied Science. pp 30-50. 